\title{
The gap between user perceptions and expectations of students at the main library of the University of KwaZulu-Natal: Pietermaritzburg Campus
}

\begin{tabular}{|c|c|}
\hline \multicolumn{2}{|c|}{$\begin{array}{l}\text { Authors: } \\
\text { Matsobane D. Kekana } \\
\text { Siyanda E. Kheswa }{ }^{2}\end{array}$} \\
\hline \multicolumn{2}{|c|}{$\begin{array}{l}\text { Affiliations: } \\
\text { 'Department of Information } \\
\text { Studies, Faculty of Arts, } \\
\text { University of Zululand, } \\
\text { KwaDlangezwa, South Africa }\end{array}$} \\
\hline \multicolumn{2}{|c|}{$\begin{array}{l}\text { Department of Information } \\
\text { Studies, College of } \\
\text { Humanities, University of } \\
\text { KwaZulu-Natal, } \\
\text { Pietermaritzburg, } \\
\text { South Africa }\end{array}$} \\
\hline \multicolumn{2}{|c|}{$\begin{array}{l}\text { Corresponding author: } \\
\text { Matsobane Kekana, } \\
\text { kekanam@unizulu.ac.za }\end{array}$} \\
\hline \multicolumn{2}{|c|}{$\begin{array}{l}\text { Dates: } \\
\text { Received: } 03 \text { Feb. } 2020 \\
\text { Accepted: } 19 \text { Apr. } 2020 \\
\text { Published: } 09 \text { July } 2020\end{array}$} \\
\hline \multicolumn{2}{|c|}{$\begin{array}{l}\text { How to cite this article: } \\
\text { Kekana, M.D. \& Kheswa, S.E., } \\
\text { 2020, 'The gap between user } \\
\text { perceptions and expectations } \\
\text { of students at the main } \\
\text { library of the University of } \\
\text { KwaZulu-Natal: } \\
\text { Pietermaritzburg Campus', } \\
\text { South African Journal of } \\
\text { Information Management } \\
\text { 22(1), a1195. https://doi. } \\
\text { org/10.4102/sajim. } \\
\text { v22i1.1195 }\end{array}$} \\
\hline \multicolumn{2}{|c|}{$\begin{array}{l}\text { Copyright: } \\
\text { (c) 2020. The Authors. } \\
\text { Licensee: AOSIS. This work } \\
\text { is licensed under the } \\
\text { Creative Commons } \\
\text { Attribution License. }\end{array}$} \\
\hline \multicolumn{2}{|l|}{ Read online: } \\
\hline 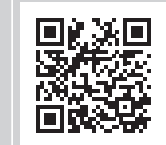 & $\begin{array}{l}\text { Scan this QR } \\
\text { code with your } \\
\text { smart phone or } \\
\text { mobile device } \\
\text { to read online. }\end{array}$ \\
\hline
\end{tabular}

Background: An academic library is defined as the heart of a university, providing a venue for students, lecturers and researchers to advance their knowledge and conduct their research. These institutions should provide learning opportunities for all who choose to use them. The materials in the library are for anyone to use, which is why university libraries are important. This study investigated the gap between postgraduate students' perception and expectations of the main academic library (Cecil Renaud) at the University of KwaZulu-Natal: Pietermaritzburg campus.

Objectives: This study's objective was to determine the gap between the existence of users' expectations and perceptions of the quality service.

Method: This study employed the quantitative research method, with a survey research design. The study population included postgraduate students in the School of Social Sciences, College of Humanities, at the University of KwaZulu-Natal: Pietermaritzburg campus.

Results: The services that have a relatively big gap in agreement between expectations and perceptions are: computers that work well, adequate number of computer workstations and an efficient short loan service, and the library helping the user to stay abreast of developments in their field of interest. On the other hand, services that have a small gap are: a library environment that has sufficient lighting; and staff willing to help, who understand the library service need and who are sufficiently knowledgeable.

Conclusion: The study found that there was a gap in almost all the services provided by the Cecil Renaud Main library. For example, with the comprehensive collection, there were not adequate print journals and books. In relation to access to information, the major gaps were re-shelving of journals, missing books and journals, and an inefficient short loan and interlibrary loan service.

Keywords: service quality; user perceptions; user expectations; postgraduate students; University of KwaZulu-Natal.

\section{Introduction}

Husain and Nazim (2015:135) state that 'academic libraries are established to support teaching, learning, research activities and development of a culture of sharing and imparting knowledge to fulfil the mission and objectives of their main institution'. A university library can be defined as the heart of the academic community, providing a venue for students, lecturers and researchers to conduct their research and advance their knowledge (Kiran 2010:261). The strategic objective of an academic library as a service organisation is to sustain the standard of service quality (Einasto 2009). The standard of services rendered should be able to satisfy the library users, and to ensure the finance of activities which are satisfactory for the existence and development of the university. These institutions are supposed to provide learning opportunities for all who choose to take advantage of them.

Ramezani et al. (2018) assert that measuring the quality of service is necessary when it comes to the planning and the improvement of the quality of the organisational services. Arshad and Ameen (2010:313) state that the role of libraries in the developed world has progressed merely from a storehouse of books and other physical artifacts to local and remotely-held databases. It has been emphasised by Quintal and Phau (2014:90) that it is clear that students are primary stakeholders in global education and their perceptions and behaviour towards the globalised learning environment in either a university's home or offshore campus are important. To start, 
their perceptions and attitude could assist teaching staff of the university to identify and put emphasis on specific attributes. Habre and Kammourie (2018) state that the library being the heart of a university campus, students' expectations and needs have had a high impact on libraries, when it came to the functionalities, services, library staff skills, learning resources and library space.

Simba (2006:1) states that the importance of academic libraries cannot be underestimated'. By saying this, it was further stressed that the reputation of a library has no measure. Academic libraries are not independent bodies of learning; they belong to the universities' community and they play an important role in the learning process of that institution. One of the most competitive obstacles for academic libraries in the 21st century is reinstating themselves as the first destination where the users go to for assistance. For users to be assisted, Brenza, Kowalsky and Brush (2015) mention that libraries should hire student assistants who can help users with duties such as providing direction, helping with computer challenges and printers and facilitating connections between the user and the librarians. Libraries should satisfy their users, with a proactive assessment of their needs and give feedback by providing a quality service that can intersect those needs. For academic libraries to add value to the learning process, they need to be both effective and efficient (Simba 2006:1). Echezona and Chigbu (2018) assert:

$[M]$ any libraries in sub-Saharan Africa have problems keeping up-to-date with information resources procurement, especially print books and journals and the concern is on the budget inadequacies they received from the institution. (p. 93)

In traditional days, before technology was developed to its current standard the library worked differently. Sahu (2007:234) states that the service 'quality of an academic library has been described in terms of its collection and measured by the size of the library holdings and statistics on its use'. According to Nitecki and Hernon (2000:259) and Deng and Zhang (2015) researchers in Library and Information Science have examined information needs, user needs, and user perceptions about the estimation of library administrations. Fasola (2015) is of the opinion that new technologies being implemented in the library can be affected by the perceptions and attitudes of librarians towards them. Fasola (2015) had taken a glimpse at an elusive idea like 'quality' as far as collections (electronic or print), and 'effectiveness' of library administrations.

\section{Research problem}

The University of KwaZulu-Natal (UKZN) libraries aim to provide high quality information services to their users, and there should be statistics proving how the users perceive the library services. Not only that, but also getting the users' expectations of the services that should be rendered. This could be accomplished through assessment because, according to McNicol (2002:251), providing support for learners is increasingly shifting major attention for libraries; it is important that approaches are developed to assist the staff in assessing the learning needs of their users and in considering ways in which those concerns could be met. Libraries are now turning to discovery products which are, according to Trapido (2016:9), 'tools and interfaces that a library implements to provide patrons the ability to search its collection and access to materials'.

According to Gannon-Leary, Bent and Webb (2008:3), 20 years ago, working spaces in a university library comprised individual study carrels, possibly bookable and enclosed, discrete spaces to use technology, often in the form of catalogue terminals and a few computers, and open reading room spaces. A research conducted through interviews by Gannon-Leary et al. (2008) on the spaces in the library claim that the virtual presence of a library rendered its physical appearance less important.

The UKZN libraries code of conduct states that users have the right to a library environment suitable for reading, study and other activities in support of research and instructional programmes (University of KwaZulu-Natal 2014). The UKZN has five campuses. Altogether, the 14 libraries contain 1.4 million volumes of collection in the form of journals, books, theses, reports and print media. Furthermore, there is an audiovisual collection and access to a number of electronic resources (e-resources). These electronic collections can be accessed through the subscriptions made by the library in the form of journals and databases.

Normally, several students see the library as an environment where they might go for reference or to be assisted in conducting research, and they do not view it as a place where they see themselves returning in the future. In this regard, the problem that this study seeks to understand is the perception of the end user regarding the service quality of the library, and to link users' perceptions and expectations with the services provided by the library.

This research has focused on the Pietermaritzburg Campus libraries; the assessment of the users' perceptions and expectations was based on the quality of services offered by Cecil Renaud Main (CRM) library. There are several studies that have been conducted about the users' perceptions and expectations of academic libraries from an internal perspective. In South Africa, there are arguably six academic libraries which have studies that evaluated their users' perceptions and expectations.

\section{Research question}

What is the gap between the existence of users' expectations and perception of quality service?

\section{Literature review}

The literature gathered indicates that there are many studies which are concerned with users' perception and expectations of quality service, and which determine how satisfied the 
users are in academic and public libraries. These studies have identified the gap between users' perceptions and users' expectations of the quality service.

Simba's (2006) study was based on the premise that the culture of library assessment from the users' perspective is of vital importance in determining users' needs and whether these needs are being met. The study examined the quality of service at Iringa University College (IUCo) library from the users' perceptions. The population of the study used was undergraduate and postgraduate students, as well as the academic staff. The insights gained from this study indicate a gap between users' expectations and perceptions.

The magnitude of the gaps found varied depending on individual services. The findings show that the most problematic services for users were electronic journals, photocopying facilities, interlibrary loans, electronic databases, and a quiet library environment. The academic staff have higher expectations and lower perceptions compared to postgraduate and undergraduate students.

A study conducted by Moon (2007) looked at the implementation of LibQUAL+ in the first South African university library, which is the Rhodes University library. Rhodes University was founded in 1904 and it had an enrolment of 6245 students. The reason for this university to embark on LibQUAL+ was influenced by the library's need to benchmark the quality of their service provision against that of other university libraries in South Africa, to fulfil requirements of the institutional audit which was conducted by the Higher Education Quality Committee.

The LibQUAL+ survey was employed to collect data. The population of the study was undergraduate and postgraduate students and academic staff. The findings on the library usage patterns were that the undergraduates were the most frequent on-site users of the library resources. In contrast, they were the least frequent users of the library's remote access facilities. The academic staff's library usage patterns show that they were less responsive to on-site usage, but exhibited high remote usage through the library website. Even though Rhodes ranked below the national average where service quality to undergraduate students was concerned, it ranked above average in some cases where all other user groups were concerned.

Other findings are on the three dimensions of LibQUAL+ which are: Affect of service, information control, and library as a place. In the dimension of 'Library as Place', Rhodes performed very poorly. A negative gap was noted between the minimum and perceived levels of service in the overall results; this attribute fell outside the zone of tolerance. On 'Information control', the findings show that the library performed very well. On the 'Affect of service', the findings show that the academic staff rated it higher than undergraduate and postgraduate students.
A study conducted by Naidu (2009) examined the quality of service provided by the Mangosuthu University of Technology (MUT) library from the perspectives of the users of the library. It determined the gaps between users' expectations and perceptions of service quality. A LibQUAL+ survey was used in this study, modified and simplified to identify these gaps. The population of the study consisted of undergraduate and postgraduate students, as well as academic and administration staff. The extent of the gap between user expectations and the actual service provided varied depending on the individual services, such as library spaces, library facilities, the library collection, and access to information.

Bhim's (2010) study examined the quality of services provided by the Bessie Head library from the perspective of the adult users of the library. The study assessed the adult users' perception of the quality of service and determined the level of user satisfaction at the Bessie Head library. The population consisted of 200 registered adult library users, and a LibQUAL+ survey instrument, which was modified and adapted for use in a public library, was used in this study.

The findings were that there was a gap between users' perceptions and expectations of service quality at the Bessie Head library. Some expectations were not in keeping with the actual experience at the library, for example, access to information, users experiencing problems with Internet access and the reference collections. Other findings revealed that the majority of adult users rated the overall quality of services as good and that the library was, to a large extent, excelling in service provision.

A study by Kachoka (2010) assessed undergraduate students' perceptions of the quality of service at Chancellor College library at the University of Malawi. The LibQUAL+ instrument, which was derived from the gap theory of service quality, and the SERVQUAL instrument were adapted and used in this study.

The findings of the study show that the undergraduate students had higher expectations of service quality than the perceived quality service. Furthermore, the results of the study indicated that the Chancellor College library was not meeting the minimum expectations of service quality of its users in the three dimensions of service quality: Affect of services, library as a place and information control.

A study by Pretorius (2011) looks at the shifting focus on the role of academic libraries, which may entail developing a better understanding, awareness and responsiveness to the needs of the library users. In an ever-changing environment and an age of accountability, academic libraries have to determine and demonstrate the impact of their resources and services. It is noted that service quality is not based exclusively on the perceptions of the librarians, but is also dependent on the perceptions of the users. 
This study assessed the quality to determine the perceptions of the users of the Vaal Triangle Campus library as they relate to quality service and developed a model to improve service quality. This study also determined library users' minimum expectations for services, their desired level of services and then sought to identify the extent of service they currently perceive on three dimensions, which are: Affect of service, library as place and access to information. Data collected used focus groups as well as individual interviews, and the LibQUAL+ instrument was adapted, modified and simplified to relate to the study. The findings indicated there was a gap between the perception and expectations of service quality. Ncwane's (2016) and Matiwane's (2017) studies assessed users' perceptions of the quality of service and determined the level of user satisfaction at two universities. Ncwane's (2016) study focused on the Mangosuthu University of Technology's Natural Sciences library and Matiwane's (2017) study was to determine student library users' expectations and perceptions of service quality provided by Walter Sisulu University Libraries at the Butterworth campus; both of these studies successfully adopted the LibQUAL+ instrument.

Nel and Fourie's (2016) study examined the information behaviour and expectations of veterinary researchers and their requirements for academic library services. This study believed that there was limited research conducted on veterinary researchers and the role of the library in supporting them. It used qualitative and quantitative methods to collect data from researchers and information specialists by means of questionnaires focus group interviews and citation analyses. The study uncovered that the information needs of researchers were influenced by the area of research and expectations for research output. Findings of this study reveal that there are gaps between researchers' expectations and their own perceptions of roles to fulfil. Researchers need, amongst other things, more information on sources and access, and a more personalised awareness service.

\section{Methodology}

This study is a quantitative research, an investigation used primarily for the positivism paradigm. The survey research design was chosen for this study. The population of this study included all registered postgraduate students in the School of Social Sciences of the College of Humanities at the UKZN: Pietermaritzburg campus. The total population of this study was 313 students. To get a proper sample for this study, a stratified random sampling was implemented. The sample chosen for this study was 169 students. In this study, a specific questionnaire was adopted as a data collection instrument. A specific survey was used in this pursuit, and that survey is known as a LibQUAL+ survey instrument. Statistical Package for the Social Sciences v 24.0 (IBM Corp., Armonk, New York, United States) was used to analyse the responses.

\section{Ethical consideration}

The researchers were guided by, and adhered to, the ethical code of the University of KwaZulu-Natal. The code is concerned with questions of anonymity, privacy and confidentiality of the students. The researchers obtained a gatekeepers letter and all the participants were clearly informed of the research objectives, and their consent in writing was obtained prior to participation. Ethical Clearance Number: HSS/1357/016M.

\section{Results and discussion}

This study's aim was to establish the gap between users' perception and expectations of service quality which was provided to them by the CRM library, and then to identify the strengths and weaknesses of the existing library services. Furthermore, in this section, the user perceptions and expectations of service quality are numerically reported and compared. The positive and negative responses, which are strongly agree and agree, disagree and strongly disagree, are combined together respectively to form one positive (agree) and one negative (disagree); the neutral responses from both the expectations and perceptions were also added together.

In Tables 1-6 below, the users' expectations and perceptions and the gap between them are indicated. In the agree column in the difference columns, the larger the number, the bigger the gap. Also in the neutral and disagree column in the difference columns, the smaller the number, the smaller the gap.

The gap difference between expectations and perceptions of service quality in this category was significantly low (2.9\%) for adequate electronic journals. The major gap in this category is $13(12.4 \%)$ in the print collection (books) and $18(17.1 \%)$ in print journals. The major gap in this category implies that the library has not met its users' expectations with regard to adequate print books and journals.

'Comprehensive collection' (Table 1) refers to adequate books, print journals and electronic journals that address the needs of the postgraduate library users and fulfil the

TABLE 1: Comprehensive collection.

\begin{tabular}{|c|c|c|c|c|c|c|c|c|c|}
\hline \multirow[t]{2}{*}{ Services: Comprehensive collection } & \multicolumn{3}{|c|}{ Expectations } & \multicolumn{3}{|c|}{ Perceptions } & \multicolumn{3}{|c|}{ Difference } \\
\hline & A & $\mathbf{N}$ & $\mathbf{D}$ & A & $\mathbf{N}$ & D & A & $\mathbf{N}$ & $\mathbf{D}$ \\
\hline Adequate print collection & 78 & 24 & 3 & 65 & 28 & 11 & 13 & -4 & -8 \\
\hline Adequate print journals & 75 & 22 & 8 & 57 & 36 & 12 & 18 & 14 & 4 \\
\hline Adequate electronic journals & 81 & 18 & 6 & 84 & 15 & 10 & -3 & 3 & -4 \\
\hline Total & 234 & 64 & 17 & 206 & 79 & 33 & 28 & -15 & -16 \\
\hline
\end{tabular}

Source: Kekana, M.D., 2016, 'Postgraduate students' perception of the library as an environment for reading, studying and researching at the University of KwaZulu-Natal: Pietermaritzburg Campus. Master's thesis, University of KwaZulu-Natal, Pietermaritzburg

A, Agree; N, Neutral; D, Disagree. 
objectives of the parent institution. Oyewole and Adetimiring (2015) assert that African universities, such as those in Nigeria, still find it difficult to provide efficient and effective resources. This is because of funding being a challenge facing university libraries, resulting in a decrease in acquisition of information resources like journals (print or electronic).

In relation to South Africa, a report by the International Federation of Library Associations and Institutions (2015) states that academic and research libraries are increasingly playing a crucial role in support of teaching, learning and research. It should also be noted that CRM is one of 12 libraries in UKZN and it can therefore be assumed that the funding received is divided centrally amongst their 12 libraries.

The study indicates that there is a gap between users' expectations and perceptions of service quality relating to access to information. The extent of gaps in this category vary from one service to another. The gap between the expectations and perceptions indicates a significant gap $(n=25,23.8 \%)$ for an efficient short loan service; 19 (18.1\%) for re-shelving of journals; 18 (17.1\%) for prompt corrective action regarding missing books and journals; 16 (15.2\%) for a prompt interlibrary loan service and re-shelving of books; $14(13.3 \%)$ for a catalogue that is clear and has useful information; $12(11.4 \%)$ for easily available access to electronic journals; and 3 (2.9\%) for a webpage that is clear and has useful information. The service that has a big gap in this section is the efficient short loan service.

Access to information (Table 2) for this study refers to easily available access to electronic databases, prompt interlibrary loan, an efficient short loan, prompt re-shelving of books and journals, and a catalogue that is clear and has useful information, to mention a few.

The information and resources should be properly stored, preserved and organised in a way that it is easily accessible. Hoppenfeld and Arant-Kaspar (2010) mentions that there have been cases in Texas A\&M University and their academic libraries where access to information, more specifically the course reserves collection, is strictly controlled. The situation there was that the students could only check out the materials (books and journals) for $4 \mathrm{~h}$, but they were not allowed to leave the building. The issue was not only for the print material, but also for the audiovisual collection (records or films).

In the African context, Tanzania specifically, Simba (2006) demonstrates that the users of the IUCo library had higher expectations of what the library should offer to them, which were services that allowed them easy access to information. The services that were perceived to be provided poorly were interlibrary loan services, short loan services, and adequate electronic databases. In South Africa, Durban to be specific, Naidu (2009) demonstrates that the users of the MUT library also had higher expectations and lower perceptions of services of easy access to electronic databases and adequate print library collection.

The facilities in the library equipment category (Table 3) showed a large gap in all four statements. The first major gap of $27(25.7 \%)$ was for the computers that work well, followed by $25(23.8 \%)$, which was for the adequate number of computer workstations. There was a gap of 19 (18.1\%) for adequate printing facilities and $17(16.2 \%)$ for the adequate

TABLE 2: Access to information.

\begin{tabular}{|c|c|c|c|c|c|c|c|c|c|}
\hline \multirow[t]{2}{*}{ Services: Access to information } & \multicolumn{3}{|c|}{ Expectations } & \multicolumn{3}{|c|}{ Perceptions } & \multicolumn{3}{|c|}{ Difference } \\
\hline & A & $\mathbf{N}$ & D & A & $\mathbf{N}$ & D & A & $\mathbf{N}$ & D \\
\hline Access to electronic databases & 88 & 13 & 4 & 76 & 18 & 11 & 12 & -5 & -7 \\
\hline Prompt interlibrary loan service & 73 & 28 & 4 & 57 & 38 & 10 & 16 & -10 & -6 \\
\hline Efficient short loan service & 76 & 23 & 6 & 51 & 41 & 13 & 25 & -18 & -7 \\
\hline Prompt re-shelving of books & 71 & 24 & 10 & 55 & 33 & 17 & 16 & -9 & -7 \\
\hline Prompt re-shelving of journals & 69 & 31 & 5 & 50 & 43 & 11 & 19 & -12 & -6 \\
\hline Clear library catalogue & 84 & 18 & 3 & 70 & 28 & 7 & 14 & -10 & -7 \\
\hline Corrective action for missing materials & 64 & 31 & 10 & 46 & 44 & 15 & 18 & -13 & -5 \\
\hline Clear library webpage & 80 & 16 & 9 & 83 & 13 & 9 & -3 & 3 & 0 \\
\hline Total & 605 & 184 & 51 & 488 & 258 & 93 & 117 & -74 & -42 \\
\hline
\end{tabular}

Source: Kekana, M.D., 2016, 'Postgraduate students' perception of the library as an environment for reading, studying and researching at the University of KwaZulu-Natal: Pietermaritzburg Campus. Master's thesis, University of KwaZulu-Natal, Pietermaritzburg

A, Agree; N, Neutral; D, Disagree.

TABLE 3: Library equipment.

\begin{tabular}{|c|c|c|c|c|c|c|c|c|c|}
\hline \multirow[t]{2}{*}{ Services: Library equipment } & \multicolumn{3}{|c|}{ Expectations } & \multicolumn{3}{|c|}{ Perceptions } & \multicolumn{3}{|c|}{ Difference } \\
\hline & A & $\mathbf{N}$ & D & A & $\mathbf{N}$ & D & A & $\mathbf{N}$ & D \\
\hline Adequate computer workstations & 54 & 25 & 26 & 29 & 34 & 42 & 25 & -9 & -16 \\
\hline Computers that work well & 63 & 18 & 25 & 36 & 30 & 39 & 27 & -12 & -14 \\
\hline Adequate photocopying facilities & 70 & 26 & 9 & 53 & 32 & 20 & 17 & -6 & -11 \\
\hline Adequate printing facilities & 68 & 25 & 12 & 49 & 28 & 28 & 19 & -3 & -16 \\
\hline Total & 255 & 94 & 72 & 167 & 124 & 129 & 88 & -30 & -57 \\
\hline
\end{tabular}

Source: Kekana, M.D., 2016, 'Postgraduate students' perception of the library as an environment for reading, studying and researching at the University of KwaZulu-Natal: Pietermaritzburg Campus. Master's thesis, University of KwaZulu-Natal, Pietermaritzburg

A, Agree; N, Neutral; D, Disagree. 
number of photocopying facilities. It could be assumed that services in this category were unsatisfactory for respondents because of large gaps that were identified for each service. However, the service with the biggest gap in this category was on the computers that work well.

This category was about an adequate number of computer workstations, computers that work well, adequate photocopying and printing facilities. The library equipment in this study plays a vital role in satisfying users' needs. Relevant resources are not all the library users expect to receive and do their work with; they also require good equipment and facilities.

When this study outlines library equipment, it refers to the Information and Communication Technologies. This equipment includes photocopy and printing machines, as well as computers and their services. They assist in the access of information for the library users, for instance, a computer which is linked to the World Wide Web gives the user access to a wide range of information, most of which can be retrieved with no charge to the users and the library offering the services.

This study revealed that in the staff services category (Table 4), there was no huge gap relating to staff services as compared to other categories. The biggest gaps in ascending orders were: $17(16.2 \%)$ for comments on the staff who are readily available; $14(13.3 \%)$ for those on the staff who instill confidence in users and staff who provide users with information skills for their work or study; 10 (9.5\%) for staff who are friendly and staff who have the knowledge to answer users' questions; 8 (7.6\%) for staff who understand the users' library service's needs; and, lastly, 3 (2.9\%) for staff who are willing to help. In this category, the three services by staff that have the biggest gap were on the staff being readily available, staff who instill confidence in users, and staff who provide users with information skills for their work or study.

In the library staff category, the study focused on staff who are friendly, instill confidence in users, are readily available to respond to queries, are willing to help, and who understand users' library service needs, to mention a few. Academic libraries, or any other library, need qualified, honest, committed and passionate staff members in order to fulfil the library's vision, which is the provision of resources to meet users' information needs. Dimarco and Van Dam (1998) assert that an academic library staff know that the library serves purposes other than purely that of preserver of the human record or gateway to information.

The study revealed that there was a gap between expectations and perceptions regarding the service of 'library as a place' (Table 5). The extent of the gap varied with the individual services. For example, the services that have a significant gap were a need for a quiet library environment which was a concern from $21(20 \%)$ students, whilst 16 (15.2\%) students said there was a need for more space for group study and learning, and $13(12.4 \%)$ students felt a need for space that inspires studying and learning. The study further revealed that $10(9.5 \%)$ students expressed a need for a safe and secure place for studying and a service that had a small gap was a library space with sufficient lighting, which was identified by $2(1.9 \%)$ students. The service with the biggest gap is the library being a quiet environment. This gap is significantly accurate because the CRM library is said to always be noisy, thus it can be assumed based on the findings that the students

TABLE 4: Staff services.

\begin{tabular}{|c|c|c|c|c|c|c|c|c|c|}
\hline \multirow[t]{2}{*}{ Services: Library staff } & \multicolumn{3}{|c|}{ Expectations } & \multicolumn{3}{|c|}{ Perceptions } & \multicolumn{3}{|c|}{ Difference } \\
\hline & A & $\mathbf{N}$ & D & A & $\mathbf{N}$ & D & A & $\mathbf{N}$ & D \\
\hline Friendly staff & 87 & 10 & 8 & 77 & 21 & 7 & 10 & -11 & 1 \\
\hline Instill confidence in users & 80 & 18 & 7 & 66 & 28 & 11 & 14 & -10 & -4 \\
\hline Readily available & 88 & 11 & 6 & 71 & 24 & 10 & 17 & -13 & -4 \\
\hline Willing to help & 84 & 14 & 7 & 81 & 17 & 7 & 3 & -3 & 0 \\
\hline Understand service needs & 83 & 17 & 5 & 75 & 20 & 10 & 8 & -3 & -5 \\
\hline Knowledgeable staff & 84 & 16 & 5 & 74 & 18 & 12 & 10 & -2 & -7 \\
\hline Information skills for study & 84 & 15 & 6 & 72 & 22 & 11 & 14 & -7 & -5 \\
\hline Total & 590 & 101 & 44 & 516 & 150 & 68 & 74 & -49 & -24 \\
\hline
\end{tabular}

Source: Kekana, M.D. 2016, 'Postgraduate students' perception of the library as an environment for reading, studying and researching at the University of KwaZulu-Natal: Pietermaritzburg Campus. Master's thesis, University of KwaZulu-Natal, Pietermaritzburg

A, Agree; N, Neutral; D, Disagree.

TABLE 5: Library as a place.

\begin{tabular}{|c|c|c|c|c|c|c|c|c|c|}
\hline \multirow[t]{2}{*}{ Services: Library as place } & \multicolumn{3}{|c|}{ Expectations } & \multicolumn{3}{|c|}{ Perceptions } & \multicolumn{3}{|c|}{ Difference } \\
\hline & A & $\mathbf{N}$ & D & A & $\mathbf{N}$ & D & A & $\mathbf{N}$ & D \\
\hline Quiet environment & 75 & 17 & 13 & 54 & 24 & 27 & 21 & -7 & -14 \\
\hline Space that inspires users & 79 & 20 & 6 & 66 & 26 & 13 & 13 & -6 & -8 \\
\hline Space for group study and learning & 75 & 22 & 8 & 59 & 35 & 11 & 16 & -13 & -3 \\
\hline Sufficient lighting & 85 & 13 & 6 & 83 & 16 & 6 & 2 & -3 & 0 \\
\hline Safe and secure space & 83 & 16 & 6 & 73 & 19 & 13 & 10 & -3 & -7 \\
\hline Total & 397 & 88 & 39 & 335 & 120 & 70 & 62 & -32 & -31 \\
\hline
\end{tabular}

Source: Kekana, M.D., 2016, 'Postgraduate students' perception of the library as an environment for reading, studying and researching at the University of KwaZulu-Natal: Pietermaritzburg Campus. Master's thesis, University of KwaZulu-Natal, Pietermaritzburg

A, Agree; N, Neutral; D, Disagree. 
making a noise are those discussing their academic work, which can be aligned with the gap of the students' need for discussion rooms or extending the hours of the current operating timetable. This can be achieved through a careful administering of the service. Also, the quietness in the library environment can be maintained through the enhancing of security personnel and a provision of sound-proofed discussion rooms to control the noise level from disturbing those not in the discussion rooms.

In this study, the library as a place investigated the critical areas and their contribution to the service quality of the library. These areas included: a quiet library environment; library space that inspires students' own study and learning; a library space for group learning and study; and a library environment that has sufficient lighting, to mention a few.

This category is critical to this study in the sense that it is the primary focus of the whole study. It is asserted by Nitecki (2011:27) that the changing paradigms of the academic library as an accumulator and preserver of knowledge resources, service provider for accessing information, facilitate intentional learning and knowledge creation among its users or researchers. The CRM library is a big building and most of the Pietermaritzburg Campus collection is housed in this library; however, there are concerns with regard to not having enough discussion rooms and other concerns which will be brought to light in the following sections. Nitecki (2011) states that library spaces do change slowly, however these changes amongst campus libraries are evident and follow planning and design processes that can happen when informed by conceptualisations that articulate not only what to place within the space but also the result of interactions between the people and their environment.

Simba (2006) discussed the results of the IUCo library as a place, and found that their library users not only expected to receive relevant resources for their work, but they also expected a suitable place to read, to search for information, to discuss with their colleagues or fellow students matters relating to their academic work, and a place to anticipate their academic activities, to outline a few. In this study, the services that had higher expectations were on their library environment having sufficient lighting and the library being a safe and secure environment. The services that had a high negative response were on the library not being a quiet environment and the library space not being conducive enough for group learning and studying. Simba (2006:104) further asserts that the IUCo library is relatively small as compared to the increasing number of its users. Naidu (2009) discusses the high expectations of the MUT library users. The results showed that a library space that inspires learning and a quiet library environment were the services that had high expectations.

The library users do not only expect to receive relevant resources for their studies, they also expect a suitable environment, for which there's comfort and inspiration when they search for information, discuss with classmates the issues related to their academic work, and an environment where they examine academic affairs.

The study revealed that there were gaps identified by students for general services (Table 6). These ranged from $23(21.9 \%)$ for the gap related to the library helping users stay abreast of developments in their field of interest, to 20 (19\%) concerning the library helping users to advance in their academic field. The study also showed that in this category the statement on the library helping users with their research needs had a small gap $(n=12,11.4 \%)$. The service that showed the biggest gap was that of the library helping users stay abreast of developments in their field of interest.

Academic libraries in general play a critical role in fulfilling the research and academic needs of the students within a university. This is asserted by Majid, Anwar and Eisenschitz (2001), who argued that a library is reflected as an important and essential component of any high quality research institute. Also, in Naidu (2009), the MUT library users also stated that their research needs were not met by the library and contradicted with Simba's (2006) study on the IUCo library, where users agreed that their library did provide for research needs. What the CRM library can attempt to implement in collaboration with the research office or academic staff is to conduct research-related workshops for postgraduate students, most especially honours and masters students, because at those levels it is imperative that the students know how to draft a comprehensive research proposal and have a clear understanding of each section therein. The CRM library can also try to emphasise the literature and advanced searching workshops for the postgraduate students, and teach them how to use certain databases.

Subject librarians should be available to the postgraduate students to assist and inform them of recent developments occurring in their field of study; this can be done through creating class alerts on the UKZN student emails for students in their different fields of study. This alert can aid the students

TABLE 6: Library services consisting of research and academic fields.

\begin{tabular}{|c|c|c|c|c|c|c|c|c|c|}
\hline \multirow[t]{2}{*}{ Services: General } & \multicolumn{3}{|c|}{ Expectations } & \multicolumn{3}{|c|}{ Perceptions } & \multicolumn{3}{|c|}{ Difference } \\
\hline & A & $\mathbf{N}$ & D & A & $\mathbf{N}$ & D & A & $\mathbf{N}$ & D \\
\hline Abreast of developments & 82 & 22 & 1 & 59 & 36 & 10 & 23 & -14 & -9 \\
\hline Advance in academic field & 84 & 20 & 1 & 64 & 32 & 9 & 20 & -12 & -8 \\
\hline Help with research needs & 87 & 15 & 3 & 75 & 24 & 3 & 12 & -9 & 0 \\
\hline Total & 253 & 57 & 5 & 198 & 92 & 22 & 55 & -35 & -17 \\
\hline
\end{tabular}

Source: Kekana, M.D., 2016, 'Postgraduate students' perception of the library as an environment for reading, studying and researching at the University of KwaZulu-Natal: Pietermaritzburg Campus. Master's thesis, University of KwaZulu-Natal, Pietermaritzburg

A, Agree; N, Neutral; D, Disagree. 
on what is new, either in their field or in research and these subject librarians can form special workshops for the students in their specific fields on how to do advance searches and properly evaluate the journals and articles accessed by them. Contrary to this, Naidu (2009:148) states that the postgraduate students in MUT library had communication barriers with the subject librarians because of unavailability.

\section{Findings}

The study found that there was a gap in almost all the services provided by the CRM library. For example, with regard to the comprehensive collection, the biggest gap was that there were not adequate print journals and print books. In relation to access to information, the major gaps were that the library was not providing an efficient short loan service and re-shelving of journals. It was also found that the library did not take corrective action regarding missing books and journals, or re-shelving of books, and there was no prompt interlibrary loan service.

The study revealed that the library equipment category had more major gaps compared to all other library services. The study found that big gaps were on computers that work well and not having an adequate number of computer workstations. In regard to the library staff, the study found that there is a major gap in staff who are not readily available to respond to the users' queries, staff who instill confidence in the users and, lastly, staff who do not provide users with the information skills needed for work or study. With the library as a place, the study found that the three major gaps were the library not being a quiet environment, the library not having sufficient space for group learning and group study, and a library space that does not inspire users' studies and learning. With regard to the library services concerning research and academic fields, the study found that there were only two big gaps, namely, on the library helping the students to stay abreast of any developments in their field of interest, and the library helping the students advance in their academic field.

This study makes the contribution that there be tools for library evaluation that assess the users' perceptions of service quality and degree of satisfaction with the mission, policies, procedures, library staff, budget and processes of the libraries. In addition, this study suggests that there are barriers to the provision of quality library services and the end-user satisfaction in academic libraries in developing countries. This study also found that the duties of library staff were to increase the level of library users' satisfaction and to assist the new students who were from previous institutions. Finally, this study also suggests that research be done using focus groups and interviews to assess any new services that are introduced in the library.

\section{Conclusion}

In summation, the students' expectations were higher than their perceptions of what the library provided. A gap does exist between the users' expectations and perceptions.
The perceptions they had of the library services were not in line with their expectations, which resulted in a gap in quality service and service delivery.

The results indicated that the CRM library is deficient in quality service, and the library staff should be encouraged to help users to define and satisfy the quality information needs and provide a standard library service quality. For the library to operate smoothly the CRM library should provide easy access to information, update its library equipment, improve in terms of the staff services, and also improve the 'library as a place'.

The library users had high expectations for most of the services in each category, for instance, comprehensive collection, access to information, library staff, the library as a place and general services. However, their perceptions varied from their expectations in many instances. The students' perceptions were lower in comparison with their expectations of the service quality at the CRM library.

\section{Acknowledgements}

The authors would like to acknowledge the postgraduate students of the University of KwaZulu-Natal for their time and effort in making this study possible.

\section{Competing interests}

The authors have declared that no competing interest exists.

\section{Authors' contributions}

M.D.K. devised the topic for the Master's research thesis and S.E.K. helped in refining it in his capacity as the supervisor. M.D.K. was responsible for drafting the article out of the master's study and sent it to S.E.K. for review and positioning. Both M.D.K. and S.E.K. contributed to the design and implementation of the research, to the analysis of the results and to the writing of the manuscript.

\section{Funding information}

This research received no specific grant from any funding agency in the public, commercial or not-for-profit sectors.

\section{Data availability statement}

Any data that support the findings of this study are included within the article.

\section{Disclaimer}

The views and opinions expressed in this article are those of the authors and do not necessarily reflect the official policy or position of any affiliated agency of the authors.

\section{References}

Arshad, A. \& Ameen, K., 2010, 'Service quality of the University of the Punjab's libraries: An exploration of users' perception', Performance Measurement and Metrics 11(3), 313-325. https://doi.org/10.1108/14678041011098578 
Bhim, S., 2010, 'Adult user perceptions of library services provided by the Bessie Head library in Pietermaritzburg, Msunduzi, KwaZulu-Natal', MIS thesis, University of Kibrary in Pietermaritzburg, Msund
KwaZulu-Natal, Pietermaritzburg.

Brenza, A., Kowalsky, M. \& Brush, D., 2015, 'Perceptions of students working as library reference assistance at a University library', Reference Services Review 43(4), 722-736. https://doi.org/10.1108/RSR-05-2015-0026

Deng, S. \& Zhang, Y., 2015, 'User perception of social questions and answer websites for library reference services', The Electronic Library 33(3), 386-399. https://doi. org/10.1108/EL-12-2013-0213

Dimarco, S. \& Van Dam, S., 1998, 'Late night in an academic library', Library and Archival Security 14(2), 7-23. https://doi.org/10.1300/J114v14n02_03

Echezona, R.I. \& Chigbu, E.D., 2018, 'User expectations and innovative strategies for improved patronage in University libraries in Nigeria', African Journal of Library Archives and Information Science 28(1), 93-105.

Einasto, O., 2009, 'Using service quality monitoring to support library management decisions: A case study from Estania', The International Information and Library Review 41, 12-20. https://doi.org/10.1080/10572317.2009.10762793

Fasola, O.S., 2015, 'Perceptions and acceptance of librarians towards using facebook and twitter to promote library services in Oyo State, Nigeria', The Electronic Library 33(5), 870-882. https://doi.org/10.1108/EL-04-2014-0066

Gannon-Leary, P., Bent, M. \& Webb, J., 2008, 'A destination or a place of last resort? The research library of the future, its users and its librarians', Library and Information Research 32(101), 3-14. https://doi.org/10.29173/lirg65

Habre, C. \& Kammourie, H., 2018, 'Redesigning spaces for effective learning: Challenges facing Riyad Nassar Library in meeting users' perceptions and expectations', Journal of Library Administration 58(5), 519-544. https://doi.org/1 $0.1080 / 01930826.2018 .1468674$

Hoppenfeld, J. \& Arant-Kaspar, W., 2010, 'Do-it-yourself for course reserves: A student driven service in an academic library', Journal of Interlibrary Loan, Document Delivery and Electronic Reserve 20(5), 353-361. https://doi.org/10.1080/107230 Delivery and Electro
$3 \mathrm{X} .2010 .520264$

Husain, S. \& Nazim, M., 2015, 'Use of different information and communication technologies in Indian academic libraries', Library Review 64(1-2), 135-153. https://doi.org/10.1108/LR-06-2014-0070

International Federation of Library Associations and Institutions, 2015, The state of libraries in South Africa, Department of Arts and Culture, Pretoria.

Kachoka, N.D., 2010, 'Undergraduate students' perception of the quality of service at Chancellor College Library, University of Malawi', MIS thesis, University of Kwazulu Natala, Pietermaritzburg.

Kekana, M.D., 2016, 'Postgraduate students' perception of the library as an environment for reading, studying and researching at the University of KwaZuluNatal: Pietermaritzburg Campus. Master's thesis, University of KwaZulu-Natal, Pietermaritzburg.

Kiran, K., 2010, 'Service quality and customer satisfaction in academic libraries: Perspective from a Malaysian university', Library Review 59(4), 261-273. https:// doi.org/10.1108/00242531011038578

Majid, S., Anwar, M.A. \& Eisenchitz, T.S., 2001, 'User perception of library effectiveness in Malaysian agricultural libraries', Library Review 50(4), 176-186. https://doi. org/10.1108/00242530110390451
Matiwane, N., 2017, 'User perception of education students with special reference to the quality of service at Walter Sisulu University library, Butterworth, South Africa', MIS thesis, University of KwaZulu-Natal, Pietermaritzburg.

McNicol, S., 2002, 'Learning in libraries: Lessons for staff', New Library World 103(7-8), 251-258. https://doi.org/10.1108/03074800210438073

Moon, A., 2007, 'LibQUAL+ at Rhodes University library: An overview of the South African implementation', Performance Measurement and Metrics 8(2), 72-87. https://doi.org/10.1108/14678040710760586

Naidu, Y., 2009, 'User perceptions of service quality and the level of user satisfaction at the Mangosuthu University of Technology Library, Umlazi, Durban', MIS thesis, University of KwaZulu Natal, Pietermaritzburg.

Ncwane, S., 2016, 'User perception of service quality and level of user satisfaction at the Mangosutho University of Technology's Natural science library, Umlazi, Durban', MIS thesis, University of KwaZulu-Natal, Pietermaritzburg.

Nel, M.A. \& Fourie, I., 2016, 'Information behavior and expectations of veterinary researchers and their requirements for academic library services', The Journa of Academic Librarianship 44, 44-54. https://doi.org/10.1016/j.acalib.2015. 10.007

Nitecki, D.A., 2011, 'Space assessment as a venue for defining the academic library', The Library Quarterly: Information, Community, Policy, 81(1), 27-59. https://doi. org/10.1086/657446

Nitecki, D.A. \& Hernon, P., 2000, 'Measuring service quality at Yale University libraries', The Journal of Academic Librarianship 26(4), 259-273. https://doi.org/10.1016/ S0099-1333(00)00117-8

Oyewole, O. \& Adetimiring, A., 2015, 'Lecturers and postgraduates perception of libraries as promoters of teaching, learning and research at the University of Ibadan, Nigeria', New Review of Academic Librarianship 21(1), 83-93. https://doi. org/10.1080/13614533.2014.934965

Pretorius, H.F., 2011, 'Developing a service quality model for an academic library: A case study of the North West University-Vaal triangle campus library', MIS thesis, University of South Africa, Pretoria.

Quintal, V. \& Phau, I., 2014, 'Student's perception of an internationalised learning environment', Marketing Intelligence and Planning 32(1), 89-106. https://doi. org/10.1108/MIP-04-2013-0066

Ramezani, A., Ghazimirsaeed, S.J., Azadeh, F., Esmaeilpour-Bandoni, M. \& YektaKooshali, M.H., 2018, 'A meta-analysis of service quality of Iranian university libraries based on the LibQUAL model', Performance Measurement and Metrics 19(3), 186-202. https://doi.org/10.1108/PMM-05-2017-0014

Sahu, A.K., 2007, 'Measuring service quality in an academic library: An Indian case study', Library Review 56(3), 234-243. https://doi.org/10.1108/00242530710736019

Simba, C.A., 2006, 'User perception of quality of service at Iringa University College Library, Tumaini University, Tanzania', MIS thesis, University of KwaZulu Natal, Pietermaritzburg.

Trapido, I., 2016, 'Library discovery products: Discovering user expectations through failure analysis', Information Technology and Libraries 35(3), 9-26. https://doi. org/10.6017/ital.v35i3.9190

University of KwaZulu-Natal, 2014, UKZN libraries, viewed 15 March 2016, from http://library.ukzn.ac.za/TopNav/Generallnformation/Aboutus919.aspx. 